\title{
Enzyme kinetics and its relevance to enzyme assay
}

\author{
J. H. WILKINSON
}

From the Department of Chemical Pathology, Charing Cross Hospital Medical School, University of Londor

An understanding of the basic principles of enzyme reactions is essential if a proper choice of assay methods is to be made and if the results of such assays are to be correctly interpreted. In this paper I propose to confine myself to those aspects of the subject which are of direct relevance to the methods commonly employed in chemical pathology.

\section{Equilibria in Enzyme Reactions}

The reversible oxidation of lactate by lactate dehydrogenase (EC 1·1·1 27),

pyruvate $+\mathrm{NADH}+\mathrm{H}^{+} \underset{p \mathrm{H} 9 \cdot 2}{\stackrel{p \mathrm{H} \cdot 4}{\rightleftarrows}}$ lactate $+\mathrm{NAD}^{+}$,

may be regarded as a typical enzyme reaction which can proceed in either direction according to whether pyruvate or lactate is provided as substrate. When the reaction is started by the addition of either substrate in the presence of the appropriate coenzyme, $p \mathrm{H}$, temperature, etc, it proceeds quite rapidly at first. However, as substrate or coenzyme is consumed and the products accumulate, the rate gradually slows until an equilibrium is reached at which the forward and reverse reactions proceed at the same rate (Fig. 1).

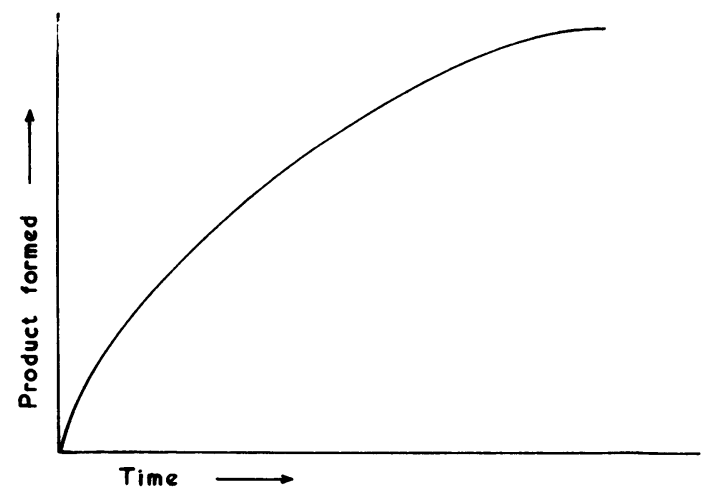

Fig. 1 Course of an enzyme reaction showing the relation between the amount of product formed and time.
In this reaction the equilibrium favours the formation of lactate, and under optimal conditions the reduction of pyruvate occurs at about 2.5 times the maximal rate of oxidation of lactate. There areo various factors which control enzyme reaction rates $\frac{8}{8}$ (1) the substrate concentration; (2) the substrateis and product inhibition; (3) $p \mathrm{H}$; (4) the temperature $; \overrightarrow{\vec{p}}$ (5) the presence of coenzymes and activators; and (6) the absence of inhibitors.

Effect of Substrate Concentration on Reaction Rates In most clinical enzyme procedures the enzyme solution (usually serum) is mixed with buffer at the optimal $p \mathbf{H}$. Coenzymes, activators, etc, are added, and the reaction is started by the addition of excess substrate. Thus at zero time, the concentration of substrate is relatively high and that of the produs s? is practically zero. Under these conditions the reaction is essentially unidirectional, and since the enzyme is fully saturated with substrate the amount of product formed is rectilinear with respect to time $\stackrel{\mathbb{D}}{\mathbb{Q}}$ ie, the reaction follows zero order kinetics.

As substrate is consumed its concentration ceases to be adequate to saturate the enzyme and the reac- tion rate becomes proportional to the substrate concentration. In other words the reaction obeys first order kinetics $(v=k[S])$. Since the calculationso are rather cumbersome when first order conditions are employed, practically all routine clinical methods depend upon initial reaction rates.

The basic concept of enzyme kinetics is expressed by the Michaelis-Menten equation, which is derived? from the generally accepted assumption that enzyme- $\rightarrow$ catalyzed reactions involve the formation of an enzyme-substrate complex which may then dissociaten in either of two ways:

$$
\mathrm{E}+\mathrm{S} \underset{\mathrm{k}_{-1}}{\stackrel{\mathrm{k}_{+1}}{\rightleftharpoons}} \mathrm{ES} \underset{\mathrm{k}_{-2}}{\stackrel{\mathrm{k}_{+2}}{\rightleftharpoons}} \mathrm{E}+\mathrm{P}
$$

where $\mathrm{E}, \mathrm{S}$, and $\mathrm{P}$ represent the concentrations of enzyme, substrate, and products respectively and ESS that of the enzyme-substrate complex.

From the law of mass action, when [ES] constant 
$\mathbf{k}_{+_{1}}[E][S]+\mathbf{k}_{-_{2}}[E][P]=\mathbf{k}_{-_{1}}[E S]+\mathbf{k}_{+_{2}}[E S] \ldots$ (2)

At the initial stage $[\mathrm{P}]$ is practically zero and $[\mathrm{S}]$ is virtually constant, so (2) reduces to

$\mathrm{k}_{+1}[\mathrm{E}][\mathrm{S}]=[\mathrm{ES}]\left(\mathbf{k}_{-1}+\mathrm{k}_{+2}\right)$

or $\frac{[\mathrm{E}][\mathrm{S}]}{[\mathrm{ES}]}=\frac{\mathbf{k}_{-1}+\mathbf{k}_{+2}}{\mathbf{k}_{+1}}=\mathrm{K}_{\mathrm{m}}$

where $\mathrm{K}_{\mathrm{m}}$ is the Michaelis constant.

The Michaelis constant is fundamental. It is characteristic of an enzyme and is frequently used in clinical work to define a given enzyme. It is expressed in concentration units and is a reciprocal measure of the affinity of an enzyme for its substrate. It may be evaluated as follows:

The Michaelis-Menten equation may be written in the form

$\mathbf{v}=\frac{[\mathrm{S}] \mathrm{V}_{\max }}{[\mathrm{S}]+\mathrm{K}_{\mathrm{m}}}$

where $\mathrm{v}$ is the reaction rate at substrate concentration [S] and $\mathrm{V}_{\max }$ is the maximum rate at optimal substrate concentration. When $\mathrm{v}=50 \%$ of $\mathrm{V}_{\max }$, (5) reduces to:

$\mathbf{K}_{\mathbf{m}}=[\mathbf{S}]$

ie, $K_{m}$ is the substrate concentration at which the reaction proceeds at half the maximum rate (Fig. 2).

There are several other ways in which enzyme activity and substrate concentration can be plotted to enable the Michaelis constant to be evaluated. Perhaps the best known of these is the double

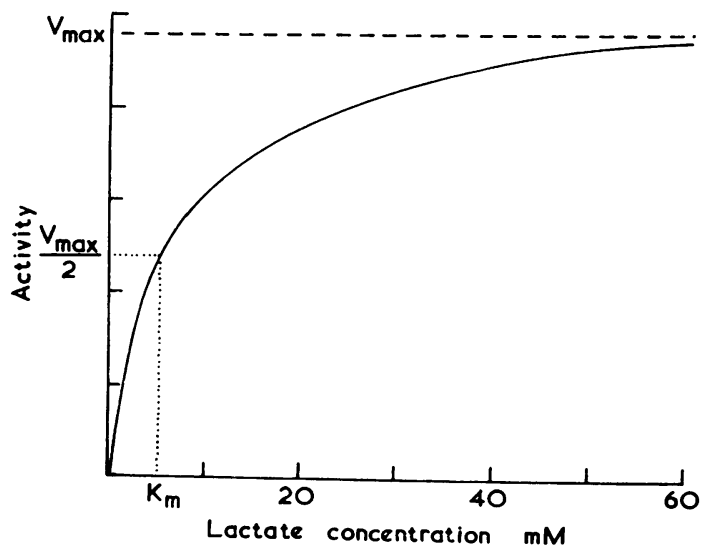

Fig 2 The effect of increasing lactate concentration on the activity of lactate dehydrogenase showing the method for the evaluation of the Michaelis constant $\left(K_{m}\right)$

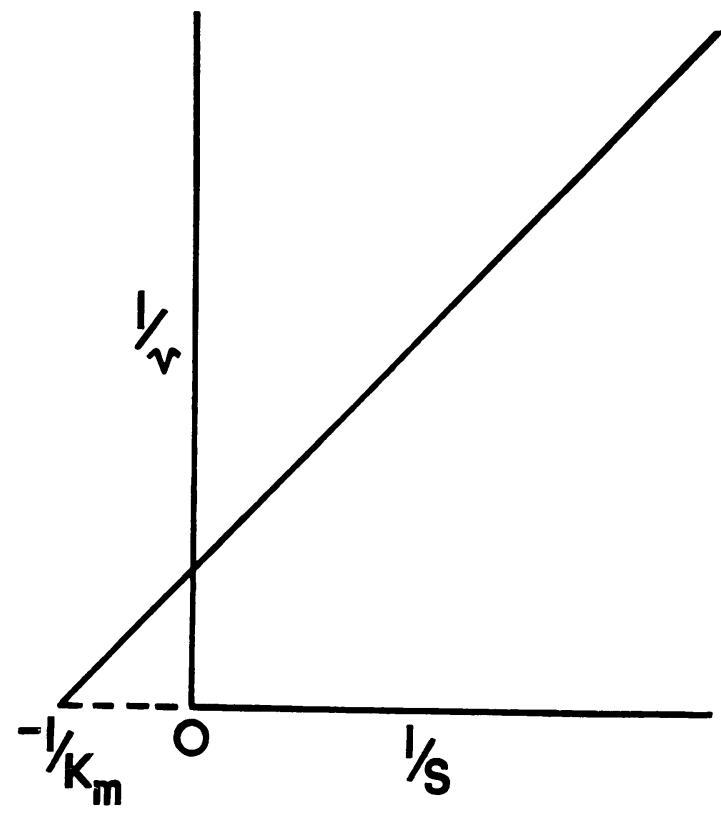

Fig. 3 Double reciprocal plot of Lineweaver and Burk showing the relationship between the reciprocal of the enzyme activity $(1 / v)$ and the reciprocal of the substrate concentration $(1 / S)$. The intercept of the plot with the abscissa gives the reciprocal of the Michaelis constant $\left(1 / K_{m}\right)$

reciprocal plot of Lineweaver and Burk (1934) illustrated in Figure 3.

When devising conditions for a new enzyme procedure it is usually convenient to start with a substrate concentration about 5-10 times the $\mathrm{K}_{\mathrm{m}}$. This is likely to be somewhere near the optimum but sometimes an increase leads to a fall in enzyme activity after a maximum has been reached. Substrate inhibition is observed when lactate dehydrogenase activity is determined with excess of pyruvate as substrate. This effect may be due to more than one substrate molecule combining with the active site of the enzyme to produce an inactive complex.

\section{Inhibitors}

The effect of inhibitors must be borne in mind when measuring enzyme activities in serum and other body fluids (Elliott and Wilkinson, 1962; Schoenenberger and Wacker, 1968). The activity of the serum aspartate aminotransferase (EC 2.6.11) from many patients with myocardial infarction or with hepatitis 


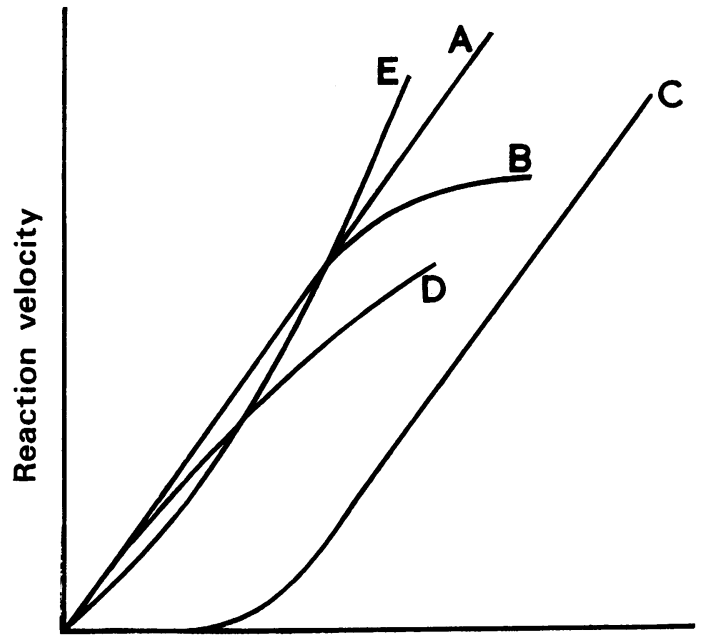

Enzyme concentration

Fig. 4 The effect of increasing enzyme concentration on the amount of substrate converted in unit time. $\mathrm{A}=$ normal response $; \mathrm{B}=$ effect of outstripping secondary reaction or substrate exhaustion; $\mathrm{C}=$ effect of toxic impurity; $\mathrm{D}=$ effect of inhibitor in enzyme preparation; $\mathrm{E}=$ effect of activator in enzyme preparation.

has been shown to deviate from linearity with increasing concentration of serum. This phenomenon is most readily explained by assuming the presence of an enzyme inhibitor in the serum.

Plotting the effects of increasing the concentration of the enzyme preparation is of considerable help in the detection of interfering substances. A normat response is indicated by a straight line relationship between the observed activity and enzyme conceno tration (Fig. 4, curve A) while increasing deviation: suggests the presence of an inhibitor in the enzyme preparation (Fig. 4, curve D). A toxic substance in the reagents produces a lag after which the responsebecomes parallel with the normal (Fig. 4, curve C) The toxic substance is taken up by the enzyme pre $\mathrm{D}$ paration until it is completely removed, after which further addition of enzyme gives a normal responses The presence of an activator in the enzyme prepara 0 tion gives a curve which becomes steeper with in $\vec{\omega}$ creasing concentration (Fig. 4, curve E), while the effects of substrate exhaustion or of outstripping secondary reaction are indicated by a fairly sharp flattening of the response (Fig. 4, curve B).

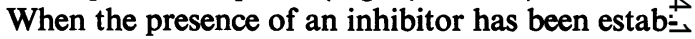
lished, Lineweaver-Burk plots in the presence and absence of the inhibitor enable the type of inhibition to be classified as competitive, non-competitive, or uncompetitive. The effects of oxalate and oxamate on lactate dehydrogenase activity are illustrated in Figure 5. Pyruvate is the substrate employed, an $\Phi$ under these conditions oxalate is a non-competitive inhibitor of the ox-heart enzyme (Novoa, Winer $\overrightarrow{0}$ Glaid, and Schwert, 1959). Though enzyme activiges are markedly reduced, there is no change in the Ke By contrast, oxamate competes with pyruvate, a while the $V_{\max }$ is unchanged, there is a markect. change in the apparent $\mathrm{K}_{\mathrm{m}}$ (Plummer and Wilkin son, 1963).

The effects of oxalate are much more pronounced on lactate dehydrogenase preparations rich in the

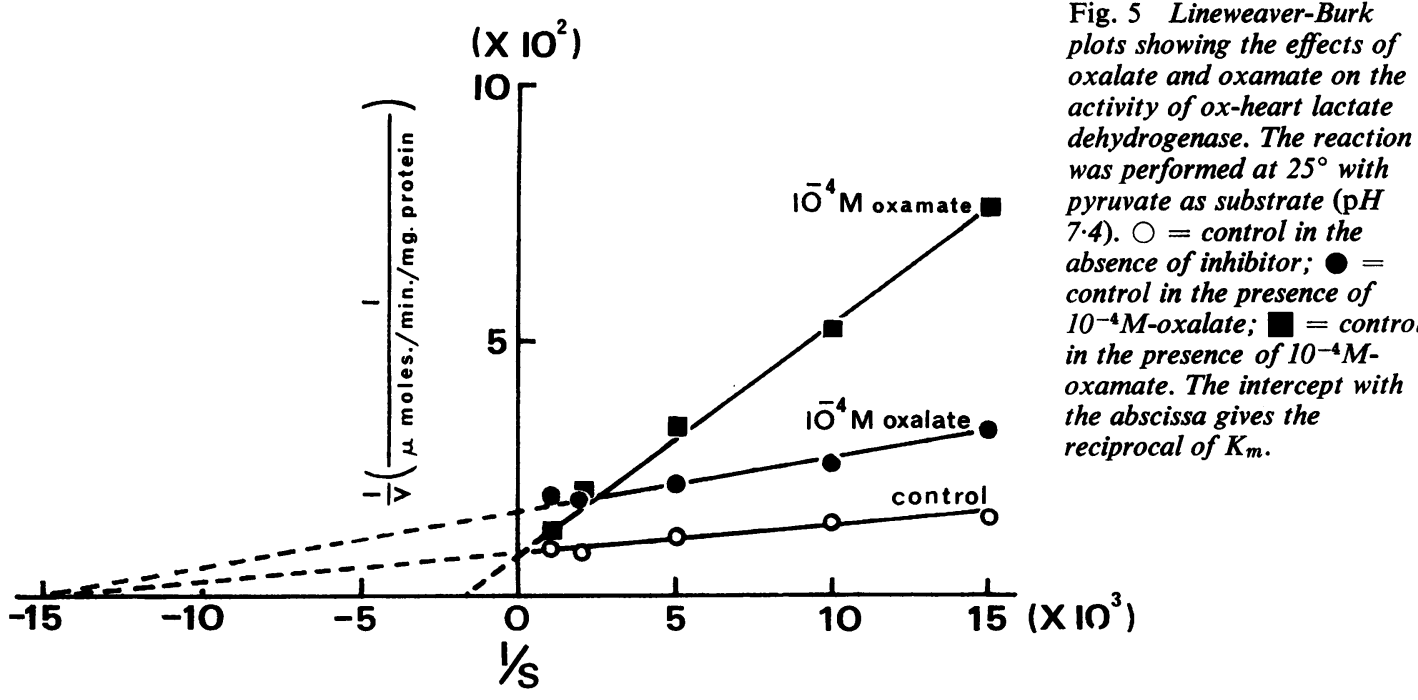

Fig. 5 Lineweaver-Burk activity of ox-heart lactate
dehydrogenase. The reaction was performed at $25^{\circ}$ with pyruvate as substrate $(\mathrm{pH}$ absence of inhibitor; $\bigcirc=$ control in the presence of $10^{-4} M$-oxalate; $\square=$ control in the presence of $10^{-4} \mathrm{M}$ oxamate. The intercept with the abscissa gives the reciprocal of $K_{m}$ 


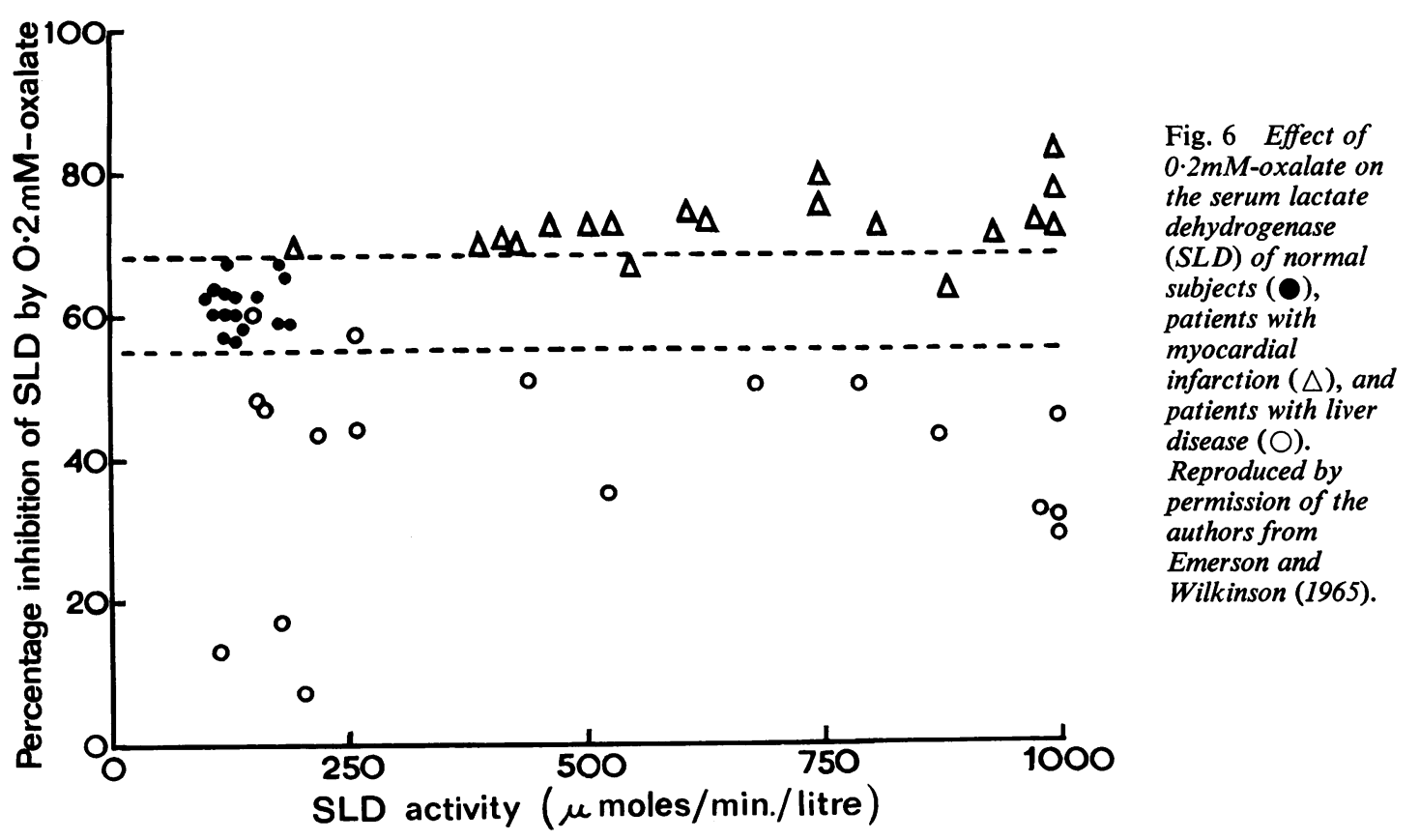

anionic isoenzyme, $L D_{1}$, than on those in which the cationic form, $\mathrm{LD}_{5}$, predominates. Thus oxalate inhibition provides a simple means of differentiating between the two isoenzymes, and can be used to distinguish between the heart and liver as the source of a raised serum lactate dehydrogenase (Emerson and Wilkinson, 1965). Some examples of the clinical application of oxalate inhibition are shown in Figure 6.

A third type of inhibition is uncompetitive, for which the explanation usually given is that the inhibitor combines with the enzyme-substrate complex (Ebersole, Guttentag, and Wilson, 1943); in this case the Lineweaver-Burk plots are parallel. My colleagues and I encountered this type of inhibition when investigating the failure of a stored sample of 2-oxobutyric acid to serve as a substrate for the '2-hydroxybutyrate dehydrogenase' reaction (Wilkinson, Jenkins, and Tuey, 1968). We found that the stored acid had undergone self-condensation to form a tetrahydrofurandionecarboxylic acid to which lactate dehydrogenase was quite inert. Part of this material, however, had decarboxylated to give 2-ethyl-3-methyltetrahydrofuran-4,5-dione (Fig. 7), which proved to be an uncompetitive inhibitor and gave the plots shown in Figure 8.

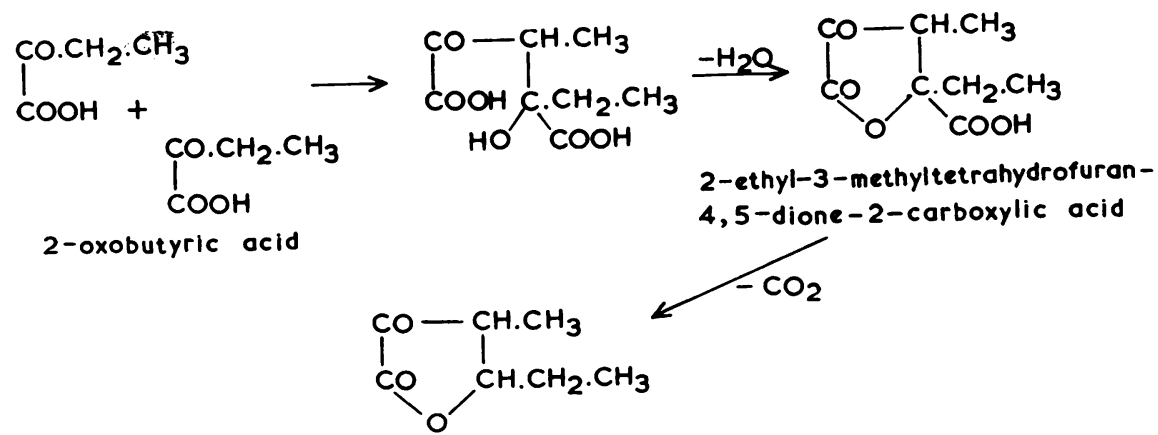

Fig. 7 Condensation of 2-oxobutyric acid to form 2-ethyl-3methyltetrahydrofuran4,5-dione, a potent inhibitor of lactate dehydrogenase.

2-ethyl-3-methyltetrahydro-

furan-4,5-dione 


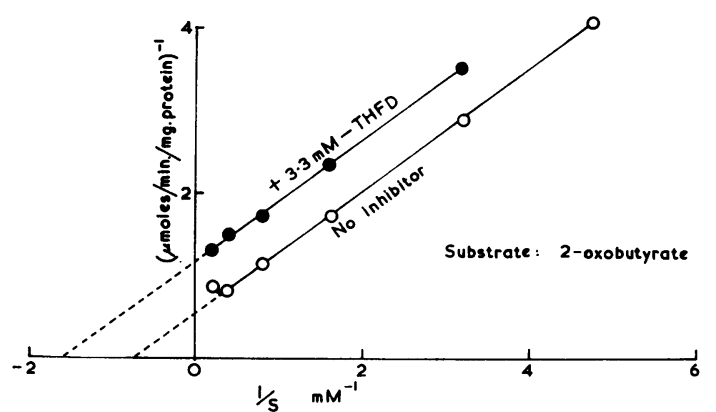

Fig. 8 Lineweaver-Burk plots showing the effect of 2-ethyl-3-methyl-tetrahydrofuran-4,5-dione (THFD) on the ' $H B D$ ' activity of ox-heart lactate dehydrogenase. The parallel plots are indicative of 'uncompetitive' inhibition. Reproduced by permission of the authors from Wilkinson et al (1968).

Coenzymes also behave like substrates and enzyme-coenzyme relationships can be expressed in terms of their Michaelis constants. An early method for the determination of serum lactate dehydrogenase with lactate as substrate and $\mathrm{NAD}^{+}$as coenzyme (Wacker, Ulmer, and Vallee, 1956) gave a reaction curve from which it was difficult to pick out a straight-line relationship at any stage. This procedure was subsequently modified by greatly increasing the coenzyme concentration (Amador, Dorfman, and Wacker, 1963). Zero-order kinetics could then be observed over a period of several minutes (Fig. 9).

However, there have been some recent reports showing that excess of $\mathrm{NAD}^{+}$might inhibit the enzyme (Babson and Arndt, 1970) and some unpublished results (Fujimoto and Wilkinson) which confirm this effect on the purified human lactate dehydrogenase isoenzymes, $\mathrm{LD}_{1}$ and $\mathrm{LD}_{5}$.

\section{Practical Problems}

I should now like to consider some practical problems which arise during enzyme determination, dealing first with relatively simple systems.

A great deal has been written and said about the comparative merits of two-point assay systems and흠 kinetic methods. The former are of course much $\frac{\bar{s}}{\widetilde{D}}$ simpler to use and require less costly equipment, but $\stackrel{\square}{\varrho}$ their reliability is suspect. In two-point assay systems measurements are only taken before and $\rightarrow$ after a fixed incubation period, and consequently ${ }_{-}^{\circ}$ there is no certainty that the rate is constant during $\vec{\omega}$ the whole of the reaction period, ie, there is no? assurance that the reaction rate is being measured under zero-order conditions. The three plots illus-is trated in Fig. 10 indicate the possibilities of error $\overrightarrow{\dot{ }}$ when such methods are employed.

The dinitrophenylhydrazone and tetrazolium- $\overrightarrow{\vec{A}}$ formazan methods for lactate dehydrogenase and음 the various methods for alkaline phosphatase areexamples of one- or two-point assay systems inc common use. In some cases the validity of these? methods can be established, especially the pro- $\cong$ cedures for alkaline phosphatase (EC 3.1.3.1) em-ploying a chromogenic substrate, eg, $p$-nitrophenyl- $\vec{\varphi}$ phosphate (Bessey, Lowry, and Brock, 1946;:Wilkinson, Boutwell, and Winsten, 1969) and phenolphthalein monophosphate (Babson, Greelef, Coleman, and Phillips, 1966; Wilkinson and Voddeñ, 1966). Only when the change in optical density can be shown to be proportional to time with several $\propto$ different enzyme preparations or sera is the use of $a=$ two-point assay system acceptable. This reservation applies with equal force to those automated pro- cedures which depend upon test or test and blank measurements only.

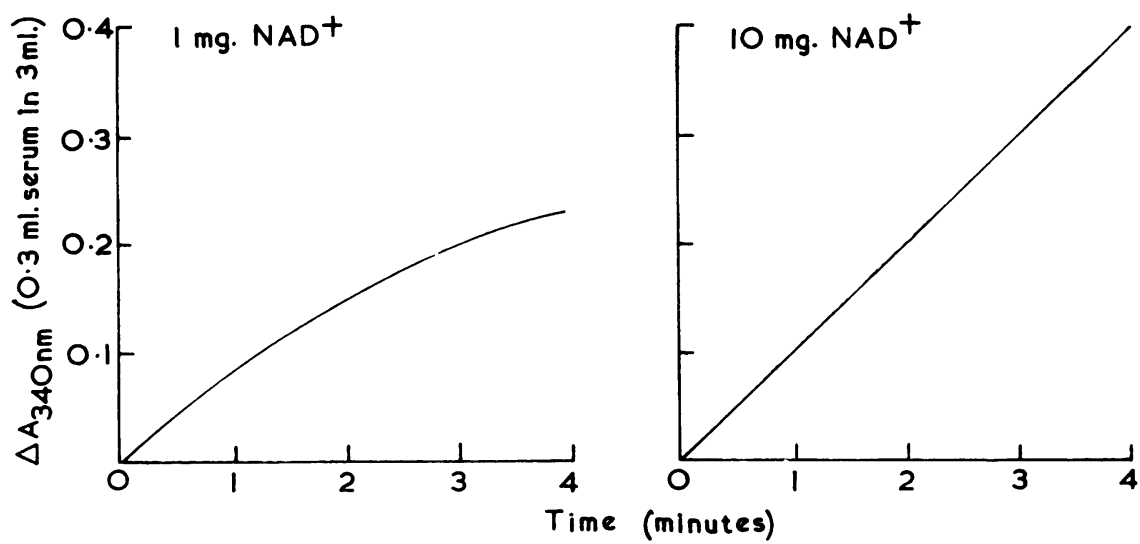

Fig. 9 Effect of increasing $N A D^{+}$ concentration on serum lactate dehydrogenase determination with lactate as substrate. 


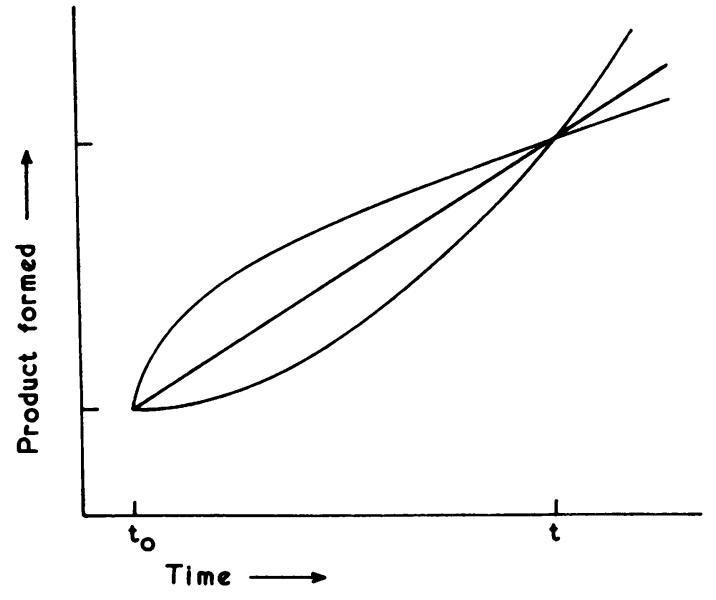

Fig. 10 Diagram showing the nature of the errors inherent in two-point assay systems. All three curves show the same amount of product formed during the incubation period, but in one case there is a falling-off in activity, and in a second there is a lag-phase. Only in the third example does the two-point assay give the true activity, characterized by the straight-line response.

Methods which record the change in optical density are preferable to two-point systems, provided that the conditions ( $p \mathrm{H}$, temperature, etc) are accurately and reproducibly controlled. A series of measurements should be made over the reaction period, and calculations of enzyme activity are based upon the rectilinear (usually the steepest) part of the curve. In contrast to two-point systems, these methods permit prompt recognition of some deviation from a straight-line response, eg, a lag period or a falling-off in the reaction rate.
Coupled Enzyme Systems

Not all enzymes can be measured quite so simply as lactate dehydrogenase or alkaline phosphatase, and numerous procedures have been devised in which the test reaction is coupled with one or more auxiliary or indicator reactions. Perhaps the best known of these is the spectrophotometric method for serum aspartate aminotransferase (Karmen, 1955), in which the oxaloacetate produced in the aminotransferase reaction is removed as fast as it is formed by an excess of malate dehydrogenase. This serves as an indicator enzyme since it is dependent upon the NAD ${ }^{+}-\mathrm{NADH}$ coenzyme system and spectrophotometric measurements at $340 \mathrm{~nm}$ can be made to follow the course of the aminotransferase reaction.

The most important requirement of coupled enzyme assay systems is that the indicator enzyme must be present in considerable excess so that the primary product-in this example, oxaloacetateis removed as it is formed, and the rate of oxidation of NADH then gives a true measure of the rate of the primary reaction.

Alternative methods for aspartate aminotransferase involve the accumulation of oxaloacetate which is a potent inhibitor of the transaminase (Boyd, 1961), and, however well they may be made to work in practice, they are theoretically unsound. Included in these are the newer diazo techniques depending upon the specific coupling of a chromogenic reagent with oxaloacetate (Babson, Shapiro, Williams, and Phillips, 1962) as well as the older dinitrophenylhydrazone procedures such as that of Reitman and Frankel (1957).

A similar coupled spectrophotometric method for alanine aminotransferase (EC 2.6.1.2), introduced by Wróblewski and LaDue (1956), depends upon the

\begin{tabular}{|c|c|c|c|c|c|}
\hline Enzyme & Medium & $\begin{array}{l}\text { Product Serving as } \\
\text { Substrate of Auxiliary } \\
\text { or Indicator Enzyme }\end{array}$ & $\begin{array}{l}\text { Auxiliary } \\
\text { Enzyme }\end{array}$ & $\begin{array}{l}N A D^{+-} \text {or } N A D P^{+}- \\
\text {dependent Indicator } \\
\text { Enzyme }\end{array}$ & Reference \\
\hline $\begin{array}{l}\text { Creatine kinase } \\
\text { (EC 2.7.3.2) }\end{array}$ & Serum & $\begin{array}{l}\text { (1) ATP } \\
\text { (2) Glucose 6-phosphate }\end{array}$ & $\begin{array}{l}\text { Hexokinase } \\
\text { (EC 2.7.1.1) }\end{array}$ & $\begin{array}{l}\text { Glucose 6-phosphate } \\
\text { dehydrogenase } \\
\text { (EC 1.1.1.49) }\end{array}$ & $\begin{array}{l}\text { Oliver (1955) } \\
\text { Rosalki (1967) }\end{array}$ \\
\hline $\begin{array}{l}\text { Pyruvate kinase } \\
\text { (EC 2.7.1.40) }\end{array}$ & Erythrocytes & Pyruvate & - & $\begin{array}{l}\text { Lactate dehydrogenase } \\
\text { (EC 1.1.1.27) }\end{array}$ & $\begin{array}{l}\text { Tanaka, Valentine, and } \\
\text { Miwa (1962) }\end{array}$ \\
\hline $\begin{array}{l}\text { Phosphoglucomutase } \\
\text { (EC 2.7.5.1) }\end{array}$ & Erythrocytes & Glucose 6-phosphate & - & $\begin{array}{l}\text { Glucose 6-phosphate } \\
\text { dehydrogenase }\end{array}$ & Joshi and Handler (1964) \\
\hline $\begin{array}{l}\text { Glucose phosphate } \\
\text { isomerase (EC 5.3.1.9) }\end{array}$ & Erythrocytes & Glucose-6-phosphate & - & $\begin{array}{l}\text { Glucose 6-phosphate } \\
\text { dehydrogenase }\end{array}$ & $\begin{array}{l}\text { Baughan, Valentine, } \\
\text { Paglia, Ways, Simon, and } \\
\text { DeMarch (1968) }\end{array}$ \\
\hline $\begin{array}{l}\text { Phosphoglycerate kinase } \\
\text { (EC 2.7.2.3) }\end{array}$ & Erythrocytes & $\begin{array}{l}\text { (1) ADP } \\
\text { (2) Pyruvate }\end{array}$ & Pyruvate kinase & Lactate dehydrogenase & $\begin{array}{l}\text { Baughan, Jaffe, and } \\
\text { Garson (1969) } \\
\text { Valentine, Hsieh, Paglia, } \\
\text { Anderson, Baughan, Jaffe } \\
\text { and Garson (1969) }\end{array}$ \\
\hline
\end{tabular}

Table Enzyme assay techniques involving coupled enzyme systems 
reduction of one of the products (pyruvate) by lactate dehydrogenase which serves as indicator enzyme. The conditions originally specified for this procedure, however, were later shown to be suboptimal, especially with regard to the concentration of alanine (Henry, Chiamori, Golub, and Berkman, 1960).

In this connexion I must mention my experience with this test at the University of Pennsylvania. In about $90 \%$ of patients in the early stages of jaundice due to virus hepatitis the serum alanine aminotransferase value exceeded that of the aspartate aminotransferase whereas at Westminster Hospital probably less than $10 \%$ showed such a relationship. The difference proved to be due to the use in the Pennsylvania laboratory of optimal conditions whereas the older method was then employed at Westminster.

Similar coupled systems may be used for the assay of many other enzymes which are not $\mathrm{NAD}^{+}$- or NADP+-dependent, but in each case the auxiliary and indicator enzymes must be present in excess, so that their reactions do not become rate-limiting. Some examples are listed in the Table. currently used for its determination are unsatisच factory in that the amount of starch hydrolysed of reducing substance formed is not proportional to the period of incubation. I am indebted to Dr Michaed. Lubran of Los Angeles, California, for the following probable explanation of the deviation from zere order kinetics. The enzyme attacks glycoside link을 ages in the middle of the starch molecule and has little or no action on the terminal linkages. As th 8 reaction proceeds, there is a gradual increase in the number of these, and as the ultimate products, maltose and maltotriose, are inhibitors of the enzyme, the reaction rate slows appreciably. ThE process is shown diagrammatically in Figure 11.

\section{References}

Amador, E., Dorfman, L. E., and Wacker, W. E. C. (1963). Serun lactic dehydrogenase activity: an analytical assessment of current assays. Clin. Chem., 9, 391-399.

Babson, A. L., and Arndt, E. G. (1970). Lactic dehydrogenase inhibitors in NAD. Clin. Chem., 16, 254-255.

Babson, A. L., Greeley, S. J., Coleman, C. M., and Phillips, G. E. (1960). Phenolphthalein monophosphate as a substrate forserum alkaline phosphatase. Clin. Chem., 12, $482-490$.

Babson, A. L., Shapiro, P. O., Williams, P. A. R., and Phillips, G. 彷 (1962). The use of a diazonium salt for the determination

$$
\begin{gathered}
\begin{array}{c}
\text { Terminal linkages } \\
\text { not attacked }
\end{array} \\
G-G-G-G-[G]_{n}-G-G-G-G-G-G-G-G-[G]_{n}-G-G-G \\
\uparrow-[G]_{n}-G-G-G-G \\
\begin{array}{c}
\text { Linkages in middle of chain } \\
\text { attacked most readily }
\end{array} \\
\begin{array}{c}
G-G \\
\text { Maltose }
\end{array} \\
\text { Both strongly inhibit } \alpha-G-G-G-[G]_{n}-G-G-G
\end{gathered}
$$

Fig. 11 The mechanism of the action of $\alpha$-amylase on starch according to $\mathrm{Dr} M$. Lubran (personal communication). As each 1,4-glycoside linkage in the middle of the starch molecule is hydrolyzed there is an increase in the number of insensitive terminal linkages. The end-products are maltose and maltotriose, both of which inhibit the enzyme. Thus there is a rapid reduction in the number of sensitive linkages and a slower increase in inhibitor concentration, both of which lead to deviation from zero-order kinetics.

\section{Kinetics of the Amylase Reaction with Starch}

In conclusion I should like to refer briefly to the extremely complicated kinetics of the enzymic hydrolysis of starch. Although $\alpha$-amylase (EC 3.2.1.1) was one of the first enzymes to be measured in the clinical laboratory, most of the methods glutamic-oxalacetic transaminase in serum. Clin. chim. Act 7, 199-205.

Baughan, M. A., Valentine, W. N., Paglia, D. E., Ways, P. O., Simone E. R., and DeMarsh, Q. B. (1968). Hereditary hemolyti anemia associated with glucosephosphate isomerase (GPM deficiency: a new enzyme defect of human erythrocytes. Blood, 32, 236-249.

Bessey, O. A., Lowry, O. H., and Brock, M. J. (1946). A method fo the rapid determination of alkaline phosphatase with five cubiक millimeters of serum. J. biol. Chem., 164, 321-329. 
Boyd, J. W. (1961). The intracellular distribution, latency and electrophoretic mobility of L-glutamate-oxaloacetate transaminase from rat liver. Biochem. J., 81, 434-441.

Ebersole, E. R., Guttentag, C., and Wilson, P. W. (1944). Nature of carbon monoxide inhibition of nitrogen fixation. Arch. Biochem., 3, 399-418.

Elliott, B. A., and Wilkinson, J. H. (1962). The relative efficiencies of some serum-enzyme tests in the diagnosis of myocardia infarction. Lancet, 2, 71-72.

Emerson, P. M., and Wilkinson, J. H. (1965). Urea and oxalate inhibition of the serum lactate dehydrogenase. J. clin. Path. 18, 803-807.

Henry, R. J., Chiamori, N., Golub, O. J., and Berkman, S. (1960). Revised spectrophotometric methods for the determination of glutamic-oxalacetic transaminase, glutamic-pyruvic transaminase, and lactic acid dehydrogenase. Amer. J. clin. Path., 34, 381-398.

Joshi, J. G., and Handler, P. (1964). Phosphoglucomutase. 1. Purification and properties of phosphoglucomutase from Escherichia coli. J. biol. Chem., 239, 2741-2751.

Karmen, A. (1955). A note on the spectrophotometric assay of glutamic-oxalacetic transaminase in human blood serum. $J$. clin. Invest., 34, 131-133.

Lineweaver, H., and Burk, D. (1934). Determination of enzyme dissociation constants. J. Amer. chem. Soc., 56, 658-666.

Novoa, W. B., Winer, A. D., Glaid, A. J., and Schwert, G. W. (1959). Lactic dehydrogenase. V. Inhibition by oxamate and by oxalate. J. biol. Chem., 234, 1143-1148.

Oliver, I. T. (1955). A spectrophotometric method for the determination of creatine phosphokinase and myokinase. Biochem. J., 61, 116-122.

Plummer, D. T., and Wilkinson, J. H. (1963). Organ specificity and lactate-dehydrogenase activity. 2. Some properties of humanheart and liver preparations. Biochem. J., 87, 423-429.

Reitman, S., and Frankel, S. (1957). A colorimetric method for the determination of serum glutamic oxalacetic and glutamic pyruvic transaminases. Amer. J. clin. Path., 28, 56-63.

Rosalki, S. B. (1967). An improved procedure for serum creatine phosphokinase determination. J. Lab. clin. Med., 69, 696-705.

Schoenenberger, G., and Wacker, W. E. C. (1968). Peptide inhibitors of lactic dehydrogenase. Isolation, characterization and specific inhibition of LDH-M $(V)$ and $\mathrm{LDH}_{4} \mathrm{H}_{4}(\mathrm{I})$ by inhibitor peptides I and II. In Enzymes in Urine and Kidney, edited by U. C. Dubach, pp. 101-112. Huber, Berne.

Tanaka, K. R., Valentine, W. N., and Miwa, S. (1962). Pyruvate kinase (PK) deficiency hereditary nonspherocytic hemolytic anemia. Blood, 19, 267-295.

Valentine, W. N., Hsieh, H., Paglia, D. E., Anderson, H. M., Baughan, M. A., Jaffé, E. R., and Garson, O. M. (1969). Hereditary hemolytic anemia associated with phosphoglycerate kinase deficiency in erythrocytes and leukocytes. A probable Xchromosome-linked syndrome. New Engl J. Med., 280, 528534.

Wacker, W. E. C., Ulmer, D. D., and Vallee, B. L. (1956). Metalloenzymes and myocardial infarction. II. Malic and lactic dehydrogenase activities and zinc concentrations in serum. New Engl. J. Med., 255, 449-456.

Wilkinson, J. H., Boutwell, J. H., and Winsten, S. (1969). Evaluation of a new system for the kinetic measurement of serum alkaline phosphatase. Clin. Chem., 15, 487-495.

Wilkinson, J. H., Jenkins, F. P., and Tuey, G. A. P. (1968). 2-Oxobutyric acid: effects of its condensation products on lactate dehydrogenase activity. Clin. chim. Acta, 19, 397-404.

Wilkinson, J. H., and Vodden, A. V. (1966). Phenolphthalein monophosphate as a substrate for serum alkaline phosphatase: an appraisal. Clin. Chem., 12, 701-708.

Wróblewski, F., and LaDue, J. S. (1956). Serum glutamic pyruvic transaminase in cardiac and hepatic disease. Proc. Soc. exp. Biol. (N.Y.), 91, 569-571. 